\title{
Penentuan Nilai Frekuensi Natural Bangunan UPT Perpustakaan UNS dengan Sensor Accelerometer pada Handphone Android
}

\author{
Rio Riantana, ${ }^{1, *}$ Darsono, ${ }^{1}$ dan Agus Triyono ${ }^{2}$ \\ ${ }^{1}$ Program Studi Fisika, Universitas Sebelas Maret Surakarta, Jl. Ir. Sutami No.36A Kentingan, Surakarta, 57126 \\ ${ }^{2}$ Stasiun Geofisika, Badan Meteorologi dan Geofisika Yogyakarta \\ Jl. Wates Km. 8, Kec. Gamping, Balecatur, Sleman, Kabupaten Sleman, Yogyakarta, 55294
}

\section{Intisari}

Penentuan nilai frekuensi natural bangunan UPT Perpustakaan UNS dengan sensor accelerometer pada handphone android telah dilakukan. Sensor utama untuk mencatat aktifitas mikrotremor adalah sensor accelerometer pada hanphone android. Pencatatan aktifitas mikrotremor dilakukan di setiap lantai bangunan UPT Perpustakaan UNS dan di permukaan tanah luar bangunan. Dari pencatatan aktifitas mikrotremor, data yang terekam dikirimkan ke server secara telemetri. Data yang tersimpan di server selanjutnya ditampilkan dalam grafik pada web monitoring mikrotremor. Data mikrotremor selanjutnya diolah dengan fungsi FFT untuk menentukan dominan frekuensi. Berdasarkan dominan frekuensi dapat diketahui rasio resonansi tanah dan bangunan UPT Perpustakaan UNS. Hasil perhitungan rasio resonansi didapatkan nilai $69.3594 .48 \%$ pada komponen NS dan 70.42-98.61\% pada komponen EW dengan status resonansi rendah di setiap lantai bangunan.

\begin{abstract}
Determination the value of buildings natural frequency of UPT perpustakaan UNS with Accelerometer sensor on an android phone has been done. The main sensor for recording micro tremor activity is Accelerometer sensor on the android phone. Microtremor activity recording is done on every building's floor of UPT Perpustakaan UNS and on the surface of land outside the building. From micro tremor activity recording, the recorded data is sent to the server by telemetry method. The data were stored on the server then displayed in the graph on the micro tremor web monitoring. Microtremor data is processed with the FFT function to determine the dominant frequency. From the dominant frequency, we find the ratio of resonance of soil and building of UPT Perpustakaan UNS. From the calculation, the value of resonance ratio is $69.35-94.48 \%$ in the NS component and $70.42-98.61 \%$ in the EW component with low resonance status on each floor of the building.
\end{abstract}

KATA KUNCI: mikrotremor, android, frekuensi natural bangunan, accelerometer, UPT Perpustakaan UNS http://dx.doi.org/10.12962/j24604682.v13i3.2838

\section{PENDAHULUAN}

Mikrotremor merupakan getaran tanah yang sangat kecil dan terus menerus yang bersumber dari berbagai macam getaran seperti, lalu lintas, angin, aktivitas manusia. Mikrotremor dapat juga diartikan sebagai getaran harmonik alami tanah yang terjadi secara terus menerus, terjebak dilapisan sedimen permukaan, terpantulkan oleh adanya bidang batas lapisan dengan frekuensi yang tetap, disebabkan oleh getaran mikro di bawah permukaaan tanah dan kegiatan alam lainnya. Mikrotremor dapat diukur dengan alat mikrotremormeter yang terdiri dari pengukur amplitudo dan periode. Dalam kajian teknik kegempaan, litologi yang lebih lunak mempunyai resiko yang lebih tinggi bila digoncang gelombang gempabumi, karena akan mengalami penguatan (amplifikasi) gelombang yang lebih besar dibandingkan de-

*E-MAIL: rioriantana@yahoo.com ngan batuan yang lebih kompak [1].

Salah satu faktor penting yang bisa digunakan untuk memprediksi bahaya gempa bumi pada suatu bangunan adalah dilakukan pengukuran resonansi antara frekuensi natural bangunan dan tanah di bawahnya [2].

Jika nilai frekuensi bangunan mendekati nilai frekuensi natural material di bawahnya, maka getaran seismik akan memunculkan resonansi pada bangunan yang akan meningkatkan stress pada bangunan tersebut [3]. Sekarang telah banyak diciptakan teknologi untuk menganalisis berbagai macam gejala alam seperti gempabumi. Teknologi di jaman sekarang sudah sangat kompleks. Tidak hanya digunakan sebagai media komunikasi antar manusia, tetapi juga sebagai media informasi antara manusia dan alam sekitar.

Android merupakan salah satu Operating System (OS) yang menguasai pasar smartphone. Android yang bersifat open source memudahkan penggunanya untuk mengoptimalkan fungsi-fungsi perangkat yang tersedia pada smartphone tersebut [4]. Di dalam perangkat android umumnya terdapat sensor gerak yaitu sensor accelerometer. Sensor accelerometer pada android ini digunakan untuk mengetahui orientasi gerak 


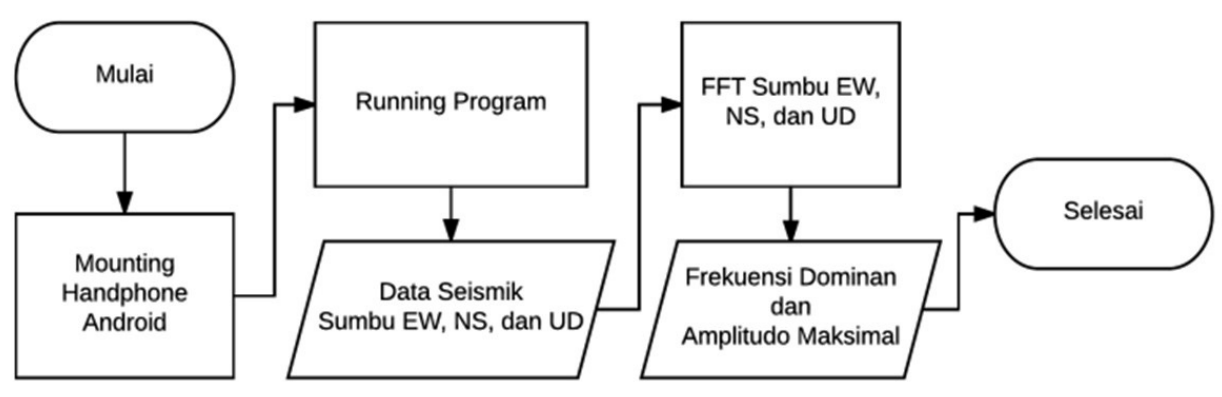

Gambar 1: Diagram alir pengambilan data mikrotremor.

pada smartphone android. Accelerometer pada smartphone android mengukur percepatan gerakan dengan satuan $\mathrm{m} / \mathrm{s}^{2}$ [5]. Sensor ini sangat sensitif dan dapat mendeteksi getaran mikrotremor.

\section{METODE PENELITIAN}

\section{Pengambilan data getaran natural tanah dan bangunan di lingkungan Gedung Perpustakaan UNS}

Pengambilan data frekuensi natural tanah dan bangunan dilakukan dengan menempatkan handphone android di permukaan tanah sekitar lingkungan gedung Perpustakaan UNS dan di beberapa titik di setiap lantai gedung Perpustakaan UNS. Handphone android ditempatkan pada mounting yang telah dibuat. Selanjutnya handphone android diatur levelingnya agar sumbu-sumbunya berada tepat sesuai dengan posisinya. Pengambilan data di setiap titik dilakukan selama kurang lebih 30 menit hingga 1 jam. Dari data getaran selama periode waktu tersebut, akan dilakukan konversi data getaran pada domain waktu ke dalam domain frekuensi. Proses konversi ini menggunakan metode Fast Fourier Transform (FFT). Diagram alir pengambilan data mikrotremor ditunjukkan Gambar 1.

\section{Teknik analisis data}

Teknik analisis data dilakukan dengan metode Fast Fourier Transform (FFT) dimana data getaran dalam domain waktu diubah ke dalam domain frekuensi.

$$
\begin{aligned}
X(f) & =\int_{\propto \propto}^{\propto} x(t) e^{-j 2 \pi f t} d t \\
& =\int_{\propto \propto}^{\propto} x(t) \cos (2 \pi f t) \\
& -j \int_{\propto \propto}^{\propto} x(t) \sin (2 \pi f t) d t
\end{aligned}
$$

$\mathrm{X}(\mathrm{f})$ merupakan fungsi sinyal dalam domain frekuensi, $\mathrm{x}(\mathrm{t})$ merupakan fungsi sinyal dalam domain waktu, $e^{-j 2 \pi f t}$ merupakan fungsi kernel, dan f adalah frekuensi. Pers.(1) merupakan fungsi yang digunakan untuk mentransformasikan sinyal dari domain waktu ke domain frekuensi.

$$
\begin{aligned}
X(f)_{E W} & =\int_{\propto \propto}^{\propto} x(t)_{E W} \cos (2 \pi f t) d t \\
& -j \int_{\propto \propto}^{\propto} x(t)_{E W} \sin (2 \pi f t) d t \\
X(f)_{N S} & =\int_{\propto \propto}^{\propto} x(t)_{N S} \cos (2 \pi f t) d t \\
& -j \int_{\propto \propto}^{\propto} x(t)_{N S} \sin (2 \pi f t) d t \\
X(f)_{U D} & =\int_{\propto \propto}^{\propto} x(t)_{U D} \cos (2 \pi f t) d t \\
& -j \int_{\propto \propto}^{\propto} x(t)_{U D} \sin (2 \pi f t) d t
\end{aligned}
$$

$\mathrm{X}(\mathrm{f})_{E W}, \mathrm{X}(\mathrm{f})_{N S}$, dan $\mathrm{X}(\mathrm{f})_{U D}$ merupakan fungsi sinyal dalam domain frekuensi pada sumbu EW, NS, dan UD. Setiap titik yang dilakukan pengukuran getaran akan mendapatkan hasil dari ketiga sumbu tersebut. Dari ketiga sumbu tersebut dapat dilakukan analisis HVSR (Horizontal to Vertical Spectral Ratio) dan FSR (Floor Spectral Ratio). Persamaan untuk HVSR ditunjukan pada Pers.(6), dan persamaan untuk FSR ditunjukan pada Pers.(7) dan (8).

$$
\begin{aligned}
H V S R & =\frac{\sqrt{\left(X(f)_{E W}\right)^{2}+\left(X(f)_{N S)^{2}}\right.}}{X(f)_{U D}} \\
F S R_{E W} & =\frac{X_{b}(f)_{E W}}{X_{t}(f)_{E W}} \\
F S R_{N S} & =\frac{X_{b}(f)_{N S}}{X_{t}(f)_{N S}}
\end{aligned}
$$

Analisis untuk getaran natural tanah menggunakan analisis HVSR dan untuk analisis pada setiap lantai bangunan menggunakan FSR. Nilai HVSR didapatkan dari perbandingan antara frekuensi getaran natural tanah pada sumbu horizontal (EW dan NS) dengan frekuensi getaran natural tanah pada sumbu vertikal (UD). Nilai FSR didapatkan dari perbandingan antara frekuensi getaran bangunan dengan frekuensi getaran tanah pada sumbu yang sama. FSR ${ }_{E W}$ merupakan frekuensi spektral lantai pada sumbu EW, dan $\mathrm{FSR}_{N S}$ merupakan frekuensi spektral lantai bangunan pada sumbu NS. Dari hasil pengolahan data akan dilakukan perhitungan rasio resonansi tanah dan bangunan dengan Pers.(9). 


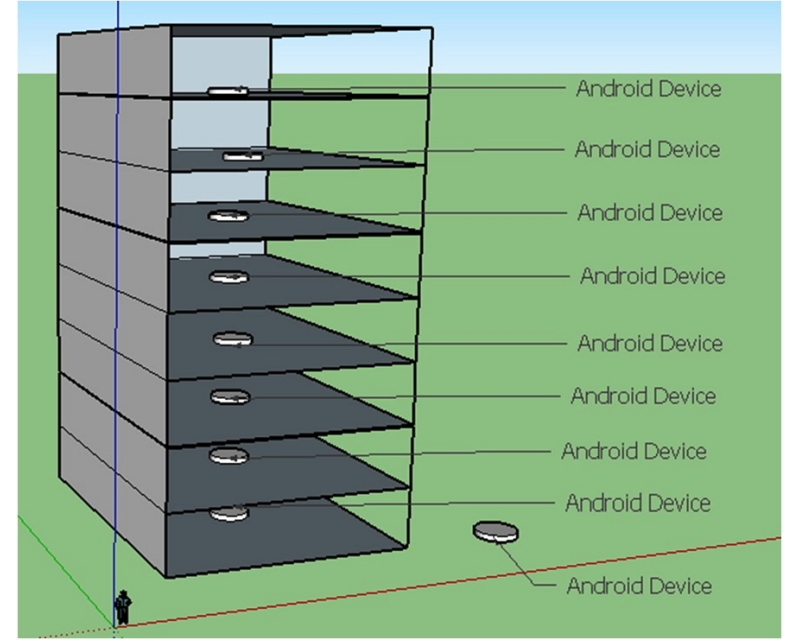

Gambar 2: Konfigurasi titik pengambilan data mikrotremor.

$$
R=\left|\frac{f b-f t}{f t}\right| \times 100 \%
$$

$\mathrm{R}$ merupakan rasio resonansi, fb merupakan resonansi bangunan, dan ft merupakan resonansi tanah. Tingkatan resonansi bangunan terhadap gempa diklasifikasikan menjadi tiga, yaitu rendah jika nilai resonansi $(\mathrm{R})>25 \%$, sedang jika nilai resonansi $(\mathrm{R})=(15-25 \%)$, dan tinggi jika nilai resonansi $(\mathrm{R})$ $<15 \%$ [6].

\section{HASIL DAN PEMBAHASAN}

\section{Data getaran natural tanah dan bangunan}

Pengambilan data mikrotremor dilakukan pada dinihari setelah jam 12 malam. Hal ini dilakukan agar suasana lokasi pengambilan data senyap sehingga gangguan yang diterima oleh alat pencatat semakin kecil. Seperti yang ditunjukan pada Gambar 2, lokasi pengambilan data mikrotremor meliputi lantai basement hingga lantai 7 Gedung UPT Perpustakaan UNS, dan di ruang terbuka sekitar halaman Gedung UPT Perpustakaan UNS. Pengambilan data di dalam gedung dilakukan dengan menempatkan handphone android di tengah gedung atau di posisi center of building. Penempatan pada lantai 2, lantai 3, lantai 4, lantai 5, lantai 6, dan lantai 7 diposisikan di depan lift gedung karena dianggap posisi tersebut adalah posisi yang paling tengah. Untuk lantai 1 lokasi penempatan handphone diletakan di depan front office. Untuk lantai basement posisi diletakan tepat dibawah posisi penempatan lantai 1. Sedangkan untuk lokasi luar gedung ditempatkan di sebelah selatan gedung UPT Perpustakaan UNS.

Pengambilan data pada setiap lantai dilakukan dengan durasi 30 sampai dengan 60 menit. Sebelum melakukan pengambilan data handphone android dipasangkan pada mounting dan diatur leveling-nya. Mounting direkatkan dengan lantai menggunakan double tape foam seperti perekatan
TABEL I: Hasil frekuensi dominan dari proses FFT dengan Matlab.

\begin{tabular}{lccc}
\hline \hline Lokasi & NS (Hz) & $\mathrm{EW}(\mathrm{Hz})$ & $\mathrm{Z}(\mathrm{Hz})$ \\
\hline Basement & 3.691 & 4.980 & 3.203 \\
Lantai 1 & 1.269 & 3.242 & 1.679 \\
Lantai 2 & 3.262 & 2.129 & 1.641 \\
Lantai 3 & 3.906 & 1.641 & 0.391 \\
Lantai 4 & 2.168 & 3.223 & 1.367 \\
Lantai 5 & 4.121 & 1.504 & 1.719 \\
Lantai 6 & 0.742 & 0.234 & 2.031 \\
Lantai 7 & 1.797 & 4.668 & 0.273 \\
Luar Bangunan & 3.945 & 4.941 & 1.855 \\
(Tanah) & & & \\
\hline \hline
\end{tabular}

TABEL II: Nilai FSR pada setiap lantai bangunan UPT Perpustakaan UNS.

\begin{tabular}{lcc}
\hline \hline Lokasi & $\mathrm{NS}$ & $\mathrm{EW}$ \\
\hline Basement & 0,93561470 & 1,0079052 \\
Lantai 1 & 0,32167300 & 0,6561424 \\
Lantai 2 & 0,82679823 & 0,4308300 \\
Lantai 3 & 0,99011407 & 0,3320158 \\
Lantai 4 & 0,54954854 & 0,6522435 \\
Lantai 5 & 1,04463726 & 0,3043478 \\
Lantai 6 & 0,18813384 & 0,0474308 \\
Lantai 7 & 0,45548162 & 0,9446641 \\
\hline \hline
\end{tabular}

pada saat proses kalibrasi. Contoh hasil cuplikan grafik rekaman mikrotremor pada lantai 1 ditunjukkan pada Gambar 3.

Setelah data mikrotremor dari semua laintai gedung UPT Perpustakaan UNS maka selanjutnya dilakukan perhitungan nilai frekuensi dominan, HVSR dan FSR. Fungsi utama adalah untuk menentukan Frekuensi Dominan. Dalam penentuan frekuensi dominan digunakan Fast Fourier Transform, Short-Time Fourier Transform, dan spektrum getaran. Fungsifungsi tersebut sudah banyak terdapat di bahasa pemrograman modern seperti C, C\#, C++, IDL, Java dan Phyton. Penentuan nilai frekuensi dominan dilakukan dengan mengolah data mikrotremor di dalam program Matlab R2013a dari pengembang MathWorks [7].

Setelah didapatkan frekuensi dominan maka dapat diketahui nilai HVSR dan FSR. Dari pengolahan frekuensi dominan didapatkan data frekuensi dominan yang ditunjukkan pada Tabel I. Grafik frekuensi dominan ditunjukkan pada Gambar 4.

Perhitungan nilai HVSR mengacu pada Pers.(6), didapatkan nilai HVSR adalah 3,407772. Sedangkan perhitungan nilai FSR mengacu pada Pers.(7) dan (8), nilai FSR pada setiap lantai bangunan UPT Perpustakaan UNS ditunjukan pada Tabel II.

\section{Analisis hasil data mikrotremor}

Analisis data dilakukan dengan membandingkan nilai FSR setiap lantai bangunan UPT Perpustakaan UNS dengan nilai HVSR tanah di sekitarnya. Hasil data nilai FSR pada Tabel 2 diolah menggunakan Pers.(9). Tingkatan resonansi bangunan terhadap gempa diklasifikasikan menjadi tiga, yaitu rendah jika nilai resonansi $(\mathrm{R})>25 \%$, sedang jika nilai resonansi 


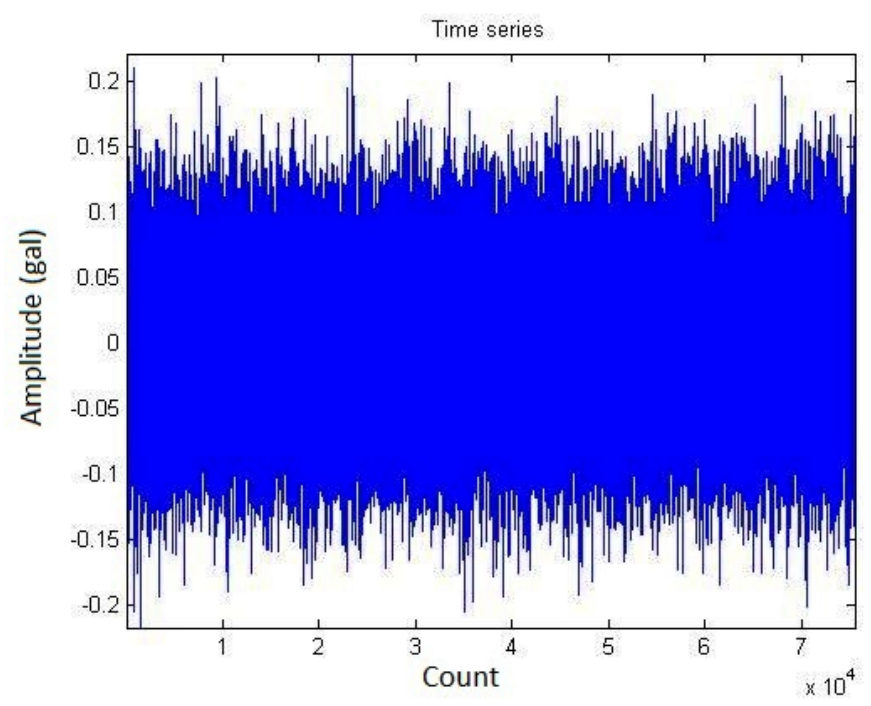

(a)

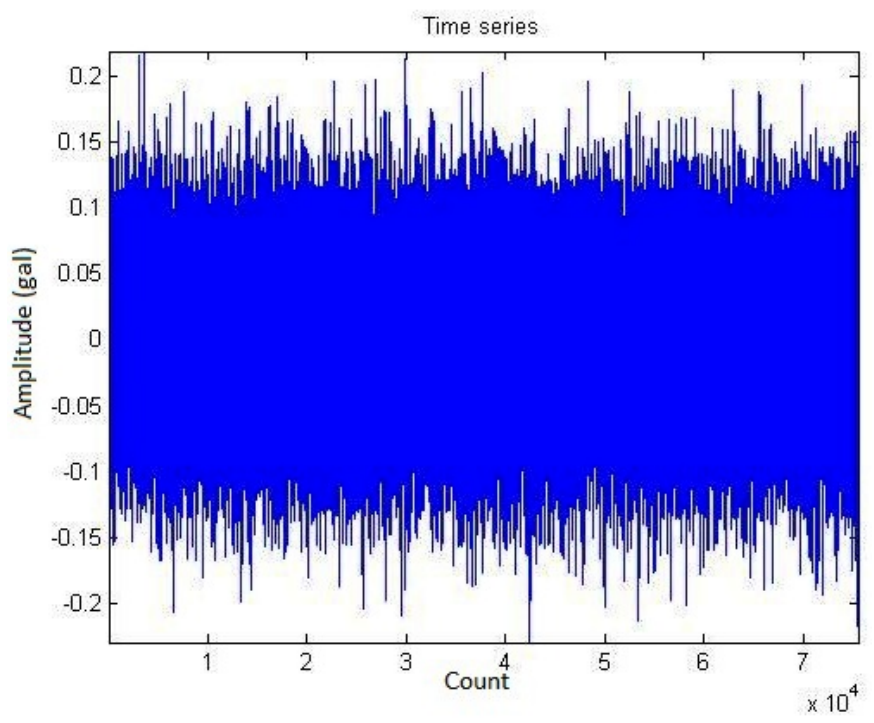

(b)

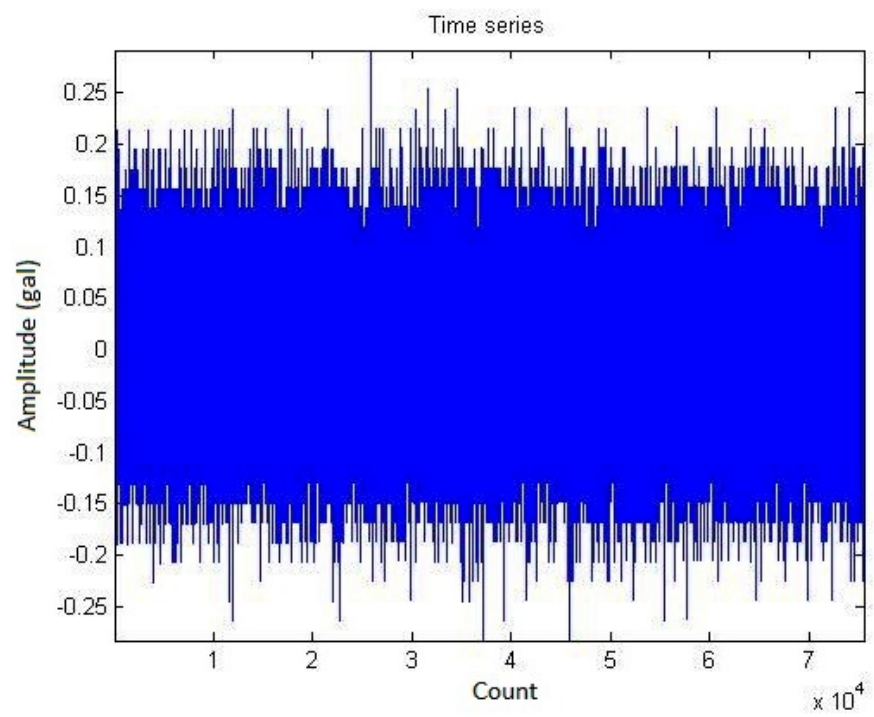

(c)

Gambar 3: Cuplikan grafik mikrotremor lantai 4 pada sumbu X (a) sumbu Y (b) dan sumbu Z (c).

$(\mathrm{R})=(15-25 \%)$, dan tinggi jika nilai resonansi $(\mathrm{R})<15 \%$ [6].

Dari hasil data yang diperoleh menunjukan bahwa rasio resonansi bangunan di setiap lantai gedung UPT Perpustakaan UNS berstatus rendah. Nilai rasio resonansi pada setiap lantai berbeda-beda. Perbedaan tersebut disebabkan karena ketinggian dari permukaan tanah, kombinasi kolom udara di bawahnya, tata ruang pada setiap lantai, dan lain-lain. Fungsi ruang pada setiap lantai juga mempengaruhi frekuensi natural pada lantai. Pada lantai basement ruangan berada di bawah permukaan tanah di luar UPT Perpustakaan UNS. Pada ruang basement ini ruangan tidak disekat-sekat melainkan ruangan yang luas dengan beberapa pilar penyangga. Frekuensi pada ruang basement ini tergolong tinggi daripada ruang-ruang lain di atasnya. Frekuensi lantai basement pada sumbu NS dan EW hampir menyamai frekuensi tanah sedangkan nilai frekuensi di sumbu z yang lebih besar. Pada lantai 1 ruangan lebih luas karena digunakan sebagai front office perpustakaan. Pada lantai 1 terdapat server internal UPT Perpustakaan UNS yang berada di sebelah selatan titik pengambilan data. Dari Tabel II diketahui bahwa nilai frekuensi dominan pada sumbu Y (NS) lebih besar daripada sumbu X (EW). Hal tersebut disebabkan adanya server internal UPT Perpustakaan UNS yang aktif. Pada lantai 2 digunakan untuk ruang Tata Usaha dan ruang pertemuan. Pada lantai 2 tidak terdapat banyak alat elektronik namun di sebelah selatan titik pengambilan data hampir sepertiga dari lantai 2 merupakan ruangan kosong tanpa lantai (dari front office langsung ke langit-langit lantai 2). Pada lantai 3 hingga lantai 6 separuh ruangan difungsikan sebagai ruang baca dan separuhnya lagi sebagai information center, mushola dan kamar mandi. Hampir di lantai tersebut nilai frekuensinya 


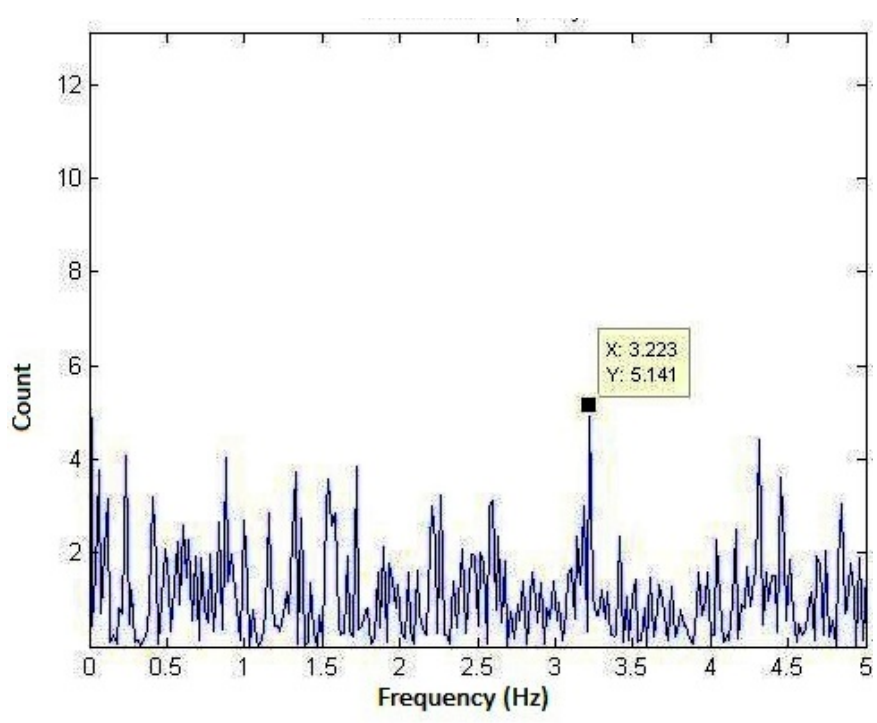

(a)

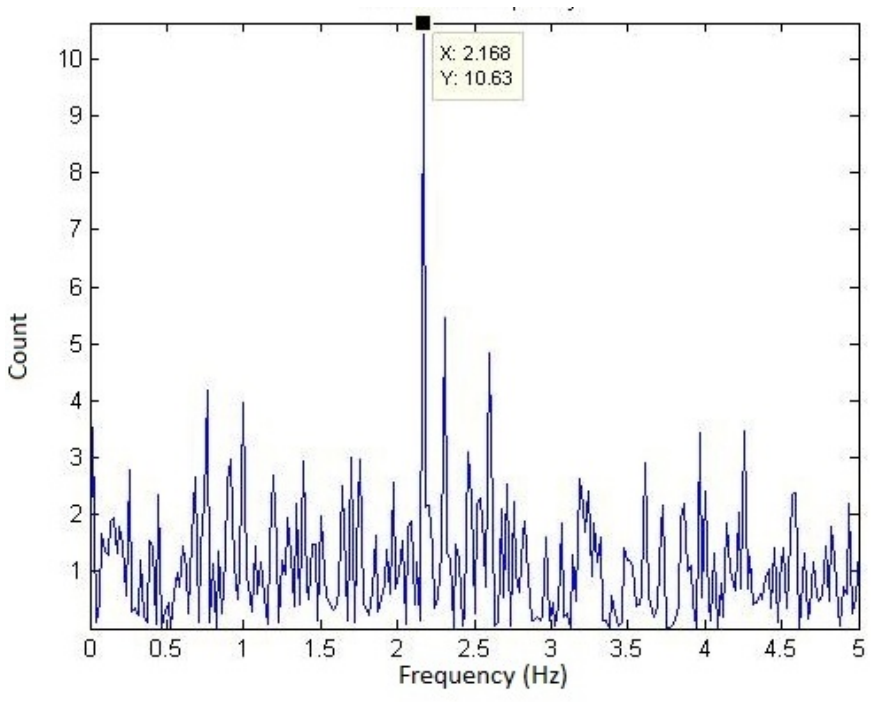

(b)

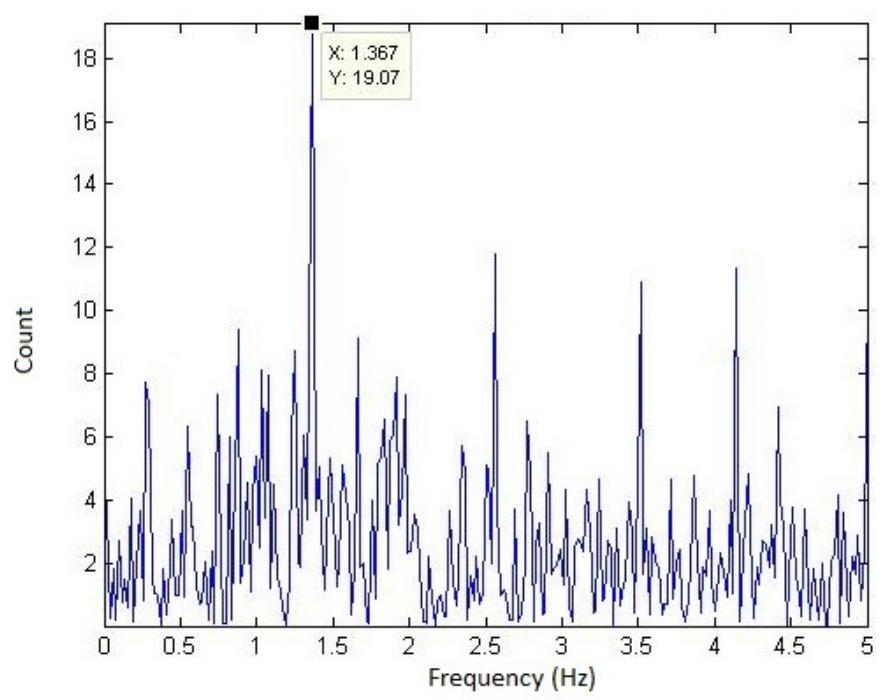

(c)

Gambar 4: Grafik frekuensi dominan EW(a), NS(b), dan UD(c) pada lantai 4 UPT Perpustakaan UNS.

TABEL III: Nilai Rasio Resonansi Bangunan UPT Perpustakaan UNS.

\begin{tabular}{lcccc}
\hline \hline Lokasi & $\begin{array}{c}\text { R(NS) } \\
\%\end{array}$ & $\begin{array}{c}\text { R(EW) } \\
\%\end{array}$ & $\begin{array}{c}\text { Status } \\
(\mathrm{NS})\end{array}$ & $\begin{array}{c}\text { Status } \\
(\mathrm{EW})\end{array}$ \\
\hline Basement & 72,54 & 70,42 & Rendah Rendah \\
Lantai 1 & 90,56 & 80,74 & Rendah Rendah \\
Lantai 2 & 75,74 & 87,36 & Rendah Rendah \\
Lantai 3 & 70,95 & 90,26 & Rendah Rendah \\
Lantai 4 & 83,87 & 80,86 & Rendah Rendah \\
Lantai 5 & 69,35 & 91,07 & Rendah Rendah \\
Lantai 6 & 94,48 & 98,61 & Rendah Rendah \\
Lantai 7 & 86,63 & 72,28 & Rendah Rendah \\
\hline \hline
\end{tabular}

hampir sama kecuali pada lantai 6 yang nilai frekuensi dominannya kecil. Pada lantai 7 fungsi dan tata ruang berbeda den- gan lantai-lantai dibawahnya. Pada lantai 7 ini difungsikan sebagai Museum UNS.

Rasio resonansi pada arah NS bervariasi antara 69,35$94,48 \%$. Rasio resonansi pada sumbu EW bervariasi antara $70,42-98,61 \%$ seperti yang ditunjukan Tabel III. Semakin besar nilai rasio resonansi maka semakin baik karena frekuensi natural pada lokasi tersebut semakin menjauhi nilai frekuensi natural tanah. Pada Tabel II menunjukan nilai frekuensi dominan berbeda-beda pada setiap sumbunya. Dalam penelitian ini untuk frekuensi dominan bangunan yang dianalisis adalah frekuensi pada sumbu horizontal yaitu NS dan EW. Orientasi getaran yang sangat mempengaruhi kekuatan bangunan pada arah horizontal. Bentuk gedung yang seperti tower membuatnya sangat rentan roboh ketika dikenai getaran khususnya getaran dengan orientasi horizontal.

Biasanya nilai frekuensi pada arah NS dan EW mendekati 


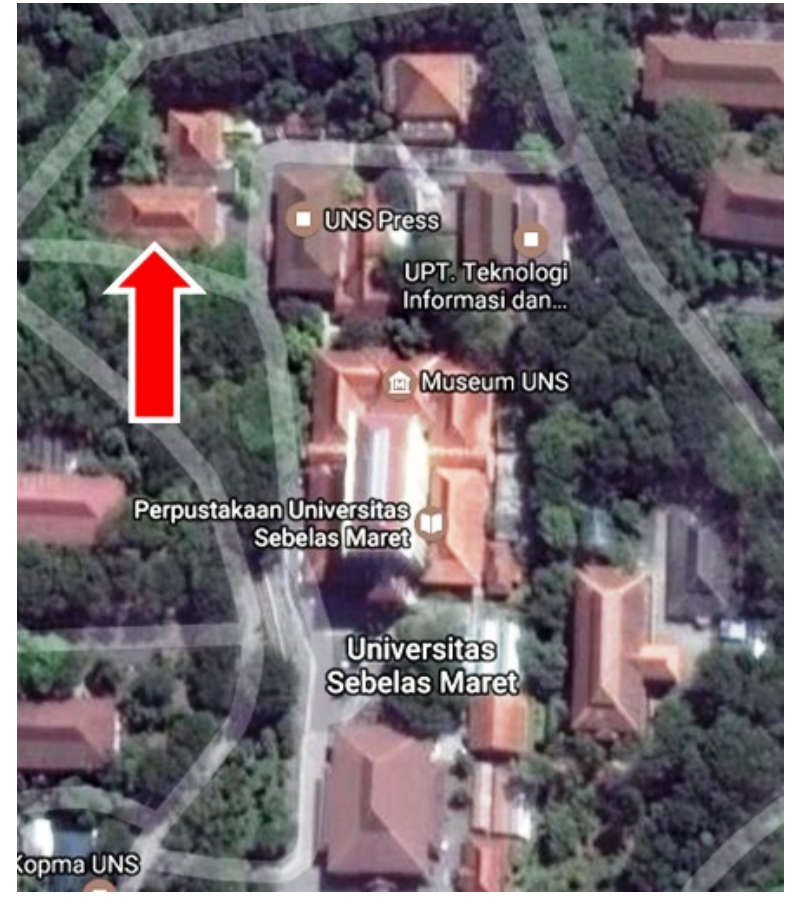

Gambar 5: Foto udara kondisi lingkungan di sekitar bangunan UPT Perpustakaan UNS.

sama atau selisihnya tidak banyak. Namun pada penelitian ini rata-rata nilai frekuensi dominan pada arah NS dan EW terdapat selisih. Hal ini dapat disebabkan oleh kondisi lokasi bangunan di sekitar gedung UPT Perpustakaan UNS. Gambar 5 menunjukan lokasi gedung UPT Perpustakaan UNS.
Gedung tersebut diapit oleh UPT TIK disebelah utara dan Auditorium UNS di sebelah selatan. Di sebelah timur dan barat gedung terlihat pepohonan. Hal ini yang menyebabkan nilai frekuensi dominan pada arah NS dan EW berbeda. Ratarata nilai frekuensi dominan pada arah NS lebih besar dari pada EW. Hal ini disebabkan karena ada pengaruh aktifitas getaran dari gedung yang mengapit di sebelah utara dan selatan. Diketahui bahwa di UPT TIK UNS terdapat banyak server yang bekerja 24 jam tanpa henti. Disebelah barat dan timur gedung UPT Perpustakaan banyak terdapat pepohonan yang dapat meredam getaran dari arah timur dan barat sehingga rata-rata getaran pada arah tersebut lebih kecil.

\section{SIMPULAN}

Nilai frekuensi natural bangunan UPT Perpustakaan UNS menunjukan bahwa rasio resonansi bangunan di setiap lantai gedung berstatus rendah. Nilai rasio resonansi pada setiap lantai berbeda-beda, perbedaan tersebut disebabkan karena ketinggian dari permukaan tanah, kombinasi kolom udara di bawahnya, tata ruang pada setiap lantai. Fungsi ruang pada setiap lantai juga mempengaruhi frekuensi natural pada lantai. Rasio resonansi pada arah NS bervariasi antara 69,3594,48\%. Rasio resonansi pada sumbu EW bervariasi antara $70,42-98,61 \%$. Semakin besar nilai rasio resonansi maka semakin baik karena frekuensi natural pada lokasi tersebut semakin menjauhi nilai frekuensi natural tanah. Rata-rata nilai frekuensi dominan pada arah NS lebih besar dari pada EW. Hal ini disebabkan karena ada pengaruh aktifitas getaran dari gedung yang mengapit di sebelah utara dan selatan.
[1] K. Kinai, Engineering Seismology (University of Tokyo, 1983).

[2] A. Gosar, Nat. Hazards Earth Syst. Sci., 10, 761-772 (2010).

[3] P. Kvasnicka, L. Matesic, K. Ivandic, Geofizika, 28, 83-97 (2011).

[4] K. Sokolovaa, C. Perezb, M. Lemerciera, Journal Decision Support Systems archive, 93(C), 62-76 (2017).

[5] R. Riantana, H. Beta, W. Cahya, dan Darsono, Jurnal Fisika dan
Aplikasinya, 11(3), 114-119 (2015).

[6] D.N. Aini, D. Utama, A.S. Bahri, Jurnal Teknik POMITS, 1(1), 1-5 (2012)

[7] R. Telgarsky, Dominant Frequency Extraction, 2013 , arXiv:1306.0103v1 [cs.NA] 1 Jun 2013 